\title{
METODE TWO STEP CLUSTER DALAM MENGELOMPOKKAN MAHASISWA FMIPA UNTAN
}

\author{
Intan Aprilia Hapsari, Dadan Kusnandar, Nurfitri Imro'ah
}

\section{INTISARI}

\begin{abstract}
Mengelompokkan objek kedalam gerombol-gerombol yang memiliki kemiripan adalah proses penggerombolan. Metode penggerombolan yang sering digunakan adalah metode berhirarki dan tak berhirarki, analisis gerombol hanya dapat digunakan jika datanya kontinu dan amatan yang relatif kecil. Penelitian ini membahas mengenai metode Two Step Cluster dengan peubah kontinu dan kategorik dalam mengelompokkan mahasiswa FMIPA Untan tahun 2018. Proses pengelompokkan metode Two Step Cluster dilakukan dengan dua tahapan. Tahap pertama gerombol awal membentuk CF Tree dengan pengukuran jarak Log-likelihood, sedangkan pada tahap pembentukan gerombol optimal dengan menghitung nilai BIC dan membandingkan rasio ukuran jarak antar gerombol. Peubah berpengaruh ditentukan dengan menggunakan uji Chi Square untuk peubah kategorik dan uji t-Student untuk peubah kontinu. Berdasarkan hasil penelitian dapat disimpulkan uji Two Step Cluster dengan menghitung nilai BIC menghasilkan dua belas gerombol maksimum dan perbandingan ukuran jarak terbesar menghasilkan tiga gerombol optimal. Gerombol satu memiliki karakteristik dengan jumlah mahasiswa berjenis kelamin perempuan lebih banyak dan seluruh mahasiswa berasal dari sekolah negeri. Gerombol kedua memiliki karakteristik mahasiswa lebih banyak berasal dari luar Kalimantan Barat dan pendidikan orang tua dari lulusan SD. Gerombol tiga dicirikan dengan karakteristik mahasiswa seluruhnya berasal dari sekolah swasta dan pendidikan orang tua berasal dari tingkat SMP. Oleh karena itu, banyak orang tua mahasiswa yang bekerja sebagai petani, pedagang dan swasta.
\end{abstract}

Kata Kunci: analisis gerombol, peubah campuran, jarak log-likelihood

\section{PENDAHULUAN}

Analisis Gerombol merupakan salah satu teknik dalam analisis peubah ganda yang bertujuan untuk menggerombolkan objek-objek berdasarkan kemiripan karakteristik yang dimiliki [1]. Terdapat dua macam metode dalam proses analisis gerombol yaitu metode berhirarki dan metode tak berhirarki [2]. Metode berhirarki digunakan apabila banyak gerombol yang akan dibentuk belum diketahui sebelumnya. Sedangkan metode tak berhirarki digunakan apabila banyak gerombol yang akan dibentuk sudah diketahui terlebih dahulu[1]. Saat ini metode pengelompokan klasik hanya terpaku pada peubah kontinu saja, sehingga dikembangkanlah metode analisis untuk mengatasi peubah yang berbeda yaitu metode Two Step Cluster.

Metode Two Step Cluster merupakan suatu metode penggerombolan yang dapat mengatasi masalah skala pengukuran yang berbeda khususnya untuk data berukuran besar dengan peubah yang memiliki tipe data kategorik dan kontinu [3]. Metode Two Step Cluster memiliki dua tahap penggerombolan yaitu tahap penggerombolan awal dan tahap penggerombolan optimal. Dalam tahap penggerombolan awal dilakukan pembentukan Cluster Feature Tree (CF Tree). Selanjutnya pembentukan gerombol optimal dilakukan dengan menghitung nilai BIC (Bayesian Information Criterion) dan membandingkan rasio ukuran jarak terbesar. Tujuan penelitian ini adalah menentukan solusi gerombol optimal pada data yang memuat peubah kontinu dan kategorik dengan menghitung nilai BIC dan rasio ukuran jarak, serta mengidentifikasi karakteristik mahasiswa FMIPA Untan menggunakan metode Two Step Cluster pada masing-masing gerombol yang terbentuk. 


\section{UKURAN JARAK}

Jarak merupakan ukuran kedekatan antara objek yang satu dengan yang lain [2]. Ukuran jarak yang ditentukan pada metode Two Step Cluster adalah jarak log-likelihood. Jarak antar gerombol $j$ dengan gerombol $s$ dapat dilihat dari persamaan berikut [4]:

$$
d(j, s)=\xi_{j}+\xi_{s}-\xi_{<j, s>}
$$

dengan:

$$
\begin{gathered}
\xi_{j}=-N\left(\sum_{k=1}^{K^{A}} \frac{1}{2} \log \left(\hat{\sigma}_{k}^{2}+\hat{\sigma}_{j k}^{2}\right)-\sum_{k=1}^{K^{B}} \sum_{l=1}^{L_{k}} \frac{N_{j k l}}{N_{j}} \log \frac{N_{j k l}}{N_{j}}\right) \\
\xi_{<j, s>}=-N\left(\sum_{k=1}^{K^{A}} \frac{1}{2} \log \left(\hat{\sigma}_{k}^{2}+\hat{\sigma}_{(j s) k}^{2}\right)-\sum_{k=1}^{K^{B}} \sum_{l=1}^{L_{k}} \frac{N_{(j s) k l}}{N_{j}} \log \frac{N_{(j s) k l}}{N_{j}}\right)
\end{gathered}
$$

dimana :

$d(j, s)$ : jarak antar gerombol $j$ dan $s$

$\xi_{j} \quad:$ log-likelihood gerombol ke- $j$

$\xi_{s} \quad:$ log-likelihood gerombol ke-s

$\xi_{<j, s>}$ : gerombol gabungan antara gerombol ke- $j$ dan gerombol ke- $s$

$N \quad$ : jumlah total objek

$K^{A} \quad$ : jumlah total peubah kontinu

$\hat{\sigma}_{k}^{2} \quad:$ ragam dugaan untuk peubah kontinu ke- $k$ untuk keseluruhan objek

$\hat{\sigma}_{j k}^{2} \quad$ : ragam dugaan untuk peubah kontinu ke- $k$ untuk keseluruhan objek dalam gerombol ke- $j$

$K^{B} \quad$ : jumlah total peubah kategorik

$L_{k} \quad$ : jumlah kategori untuk peubah kategorik ke- $k$

$N_{j} \quad$ : jumlah objek di dalam gerombol $j$

$N_{j k l} \quad$ : jumlah objek gerombol ke- $j$ untuk peubah kategorik ke- $k$ dengan kategori ke- $l$

\section{METODE TWO STEP CLUSTER}

Metode Two Step Cluster terdapan dua tahapan, yaitu penggerombolan awal dan penggerombolan optimal. Tahap gerombol awal bertujuan untuk meminimalisasi jumlah amatan yang relatif besar, yaitu objek diamati satu persatu. Kemudian ditentukan objek termasuk dalam gerombol yang telah terbentuk atau membentuk gerombol baru. Gerombol awal dilakukan dengan pembentukan CF Tree, objek yang masuk dihitung jaraknya dengan menggunakan jarak yang telah ditentukan. Pembentukan CF Tree terdiri dari dari dua tahapan. Tahap pertama yaitu tahapan penyisipan dan tahapan yang kedua adalah tahapan pembentukan kembali. Pada tahap penyisipan, secara random dipilih satu objek lalu diukur jaraknya dengan objek yang lain. Jika jarak tersebut kurang dari jarak maksimum, maka objek tersebut masuk kedalam satu gerombol [5].

Tahap pembentukan gerombol optimal, suatu gerombol dikatakan optimal apabila memiliki jarak antar gerombol paling jauh dan jarak antar objek dalam gerombol tersebut paling dekat. Semakin dekat jarak antar objek maka akan semakin besar kemiripan antar objek dalam satu gerombol. Penentuan jumlah gerombol optimal ada dua langkah yang dilakukan. Langkah pertama yaitu menghitung BIC untuk tiap-tiap gerombol untuk menentukan jumlah gerombol maksimum. Langkah kedua mencari peningkatan jarak terbesar antara dua gerombol [3]. Kriteria BIC untuk gerombol ke$j$ sebagai berikut: 


$$
B I C_{j}=-2 \sum_{j=1}^{J} \xi_{j}+m_{j} \log (N)
$$

dengan:

$$
m_{j}=J\left\{2 K^{A}+\sum_{k=1}^{K^{B}}\left(L_{k}-1\right)\right\}
$$

dimana :

$J$ : banyaknya gerombol

$m_{j}$ : jarak gerombol ke- $j$

Solusi banyaknya gerombol terbaik adalah yang memiliki nilai BIC terkecil, tetapi beberapa kasus dalam penggerombolan dimana BIC akan terus meningkat nilainya bila jumlah gerombol semakin meningkat. Dalam situasi tersebut, rasio perubahan BIC dan rasio ukuran jarak yang besar digunakan untuk mengidentifikasi solusi gerombol terbaik [5]. Pembentukan gerombol optimal memiliki dua langkah. Langkah pertama, BIC akan menghasilkan penduga awal yang baik bagi jumlah gerombol maksimum. Rasio perubahan BIC yang paling mendekati atau sama dengan nilai batas konstanta (SPSS menetapkan $c_{1}=0,04$ berdasarkan studi simulasi) menjadi gerombol maksimum yang terbentuk. Langkah kedua yaitu menghitung jumlah gerombol optimal. Banyaknya gerombol optimal dilakukan dengan menemukan perbedaan nyata pada dua rasio pengukuran jarak terbesar. Jumlah gerombol yang terbentuk dapat diketahui dari rasio ukuran jarak dengan Persamaan (3) berikut:

$$
\begin{gathered}
R(k)=\frac{d_{k-1}}{d_{k}} \\
=l_{k-1}-l_{k} \\
l_{j}=\frac{\left(m_{j} \log N-B I C_{j}\right)}{2} \text { untuk } j=k, k-1
\end{gathered}
$$

Dengan $d_{k}$ adalah jarak gerombol ke- $k ; d_{k-1}$ adalah jarak $k$ gerombol digabungkan dengan $k-1$ gerombol dan $l_{k}$ adalah galat penyimpangan gerombol ke- $k$. Penentuan banyaknya gerombol optimal dengan membandingankan dua nilai rasio terbesar $R(k)$, dihitung dengan $R\left(k_{1}\right) / R\left(k_{2}\right)$ dengan $R\left(k_{1}\right)$ adalah rasio ukuran jarak terbesar pertama dan $R\left(k_{2}\right)$ rasio ukuran jarak terbesar kedua. Jika perbandingan rasio ukuran jarak lebih besar dari pada nilai batas konstanta (SPSS menetapkan $c_{2}=1,15$ berdasarkan studi simulasi) jumlah gerombol ditetapkan sama dengan $k_{1}$, jika tidak maka jumlah gerombol optimal sama dengan maksimum $\left\{k_{1}, k_{2}\right\}[6]$.

\section{PEUBAH BERPENGARUH}

Penentuan peubah yang berpengaruh untuk mengetahui karakteristik penting setiap gerombol dilakukan menggunakan uji Chi-Square untuk peubah kategorik, dan uji t-Student untuk peubah kontinu [5];[7]. Pada uji $t$-Student yang digunakan adalah rataan dari karakteristik didalam gerombol terhadap rataan umum. Hipotesis yang diuji pada uji $t$ yaitu:

$$
\begin{aligned}
& H_{0}: \mu_{j k}=\mu_{k} \\
& H_{1}: \mu_{j k} \neq \mu_{k}
\end{aligned}
$$

Persamaan $t$ hitung sebagai berikut:

$$
t_{h i t}=\frac{\hat{\mu}_{k}-\hat{\mu}_{j k}}{\hat{\sigma}_{j k} / N}
$$


dimana :

$\hat{\mu}_{k} \quad$ : rataan peubah kontinu ke- $k$

$\hat{\mu}_{j k} \quad:$ rataan peubah kontinu ke- $k$ gerombol ke- $j$

$\hat{\sigma}_{j k} \quad$ : simpangan baku peubah kontinu ke- $k$ pada gerombol ke- $j$

$N \quad$ : jumlah objek

Jika nilai $t_{\text {hit }}>t_{\text {tabel }}$ maka hipotesis nol ditolak, artinya peubah kontinu tersebut berpengaruh terhadap gerombol.

Pada uji Chi-Square yang digunakan adalah proporsi individu atau objek antar kategorik dalam satu gerombol untuk melihat ada tidaknya hubungan antar peubah pada gerombol [3]. Hipotesis yang diuji adalah sebagai berikut:

$H_{0}$ : tidak ada hubungan antar peubah pada gerombol

$H_{1}$ : terdapat hubungan antar peubah pada gerombol

Persamaan $\chi_{\text {hit }}^{2}$ sebagai berikut:

$$
\chi_{h i t}^{2}=\sum_{i=1}^{k} \frac{(f o-f e)^{2}}{f e}
$$

dimana :

fo : frekuensi objek

fe : frekuensi harapan

Jika $\chi_{\text {hit }}^{2}$ kurang dari nilai $\chi_{\text {tabel }}^{2}$ maka hipotesis nol ditolak dan peubah kategorik berpengaruh terhadap gerombol.

\section{STUDI KASUS}

Data penelitian ini merupakan data sekunder yang diperoleh dari Subbagian Akademik dan Kemahasiswaan FMIPA Untan yang merupakan mahasiwa FMIPA Untan angkatan 2018, dengan jumlah sampel 549 mahasiswa. Peubah yang digunakan dalam penelitian ini adalah 5 peubah kategorik dan 3 peubah kontinu. Dengan peubah kategorik yaitu, $x_{1}$ adalah jenis kelamin yang terdiri dari laki-laki dan perempuan; $x_{2}$ adalah asal sekolah terdiri dari mahasiswa yang berasal dari kota Pontianak, kabupaten di Kalimantan Barat dan luar Kalimantan Barat; $x_{3}$ adalah status sekolah mahasiswa yang berasal dari sekolah negeri dan swasta; $x_{4}$ adalah pendidikan orang tua berasal dari SD, SMP, SMA sederajat dan S1 S2; $x_{5}$ adalah pekerjaan orang tua yaitu PNS BUMN, dan petani, pedagang, swasta. Sedangkan peubah kontinu yaitu $x_{6}$ adalah rata-rata nilai ujian sekolah; $x_{7}$ adalah rata-rata nilai rapor dan $x_{8}$ adalah rata-rata nilai ujian nasional.

Peubah bertipe kontinu dilakukan standarisasi data untuk mengurangi keragaman yang disebabkan oleh satuan pengukuran yang berbeda. Tahap penggerombolan awal yang dilakukan adalah pembentukan $C F$ Tree. Objek yang masuk dihitung jaraknya dengan menggunakan ukuran jarak yang telah ditentukan. Setelah terbentuk $C F$ Tree dilanjutkan dengan tahap pembentukan gerombol optimal. Untuk menentukan banyaknya gerombol optimal terdapat dua langkah yang dilakukan. Langkah pertama yaitu menghitung nilai BIC untuk setiap gerombol, hasil perhitungan tersebut digunakan untuk menentukan jumlah gerombol maksimum. Tahap kedua yaitu menentukan gerombol optimal dengan mencari ukuran jarak terbesar antara dua gerombol. Hasil analisis menggunakan software SPSS diperoleh nilai BIC untuk masing-masing gerombol pada Tabel 1 berikut: 
Tabel 1 Nilai BIC

\begin{tabular}{ccrrr}
\hline $\begin{array}{c}\text { Jumlah } \\
\text { Gerombol }\end{array}$ & BIC & $\begin{array}{c}\text { Nilai perubahan } \\
\text { BIC }\end{array}$ & $\begin{array}{c}\text { Rasio } \\
\text { perubahan BIC }\end{array}$ & $\begin{array}{c}\text { Rasio ukuran } \\
\text { jarak }\end{array}$ \\
\hline 1 & $5.345,145$ & & & \\
2 & $4.775,368$ & $-569,777$ & 1,000 & 1,466 \\
3 & $4.416,874$ & $-358,494$ & 0,629 & 1,401 \\
4 & $4.188,155$ & $-228,719$ & 0,401 & 1,042 \\
5 & $3.972,349$ & $-215,805$ & 0,379 & 1,286 \\
6 & $3.825,506$ & $-146,843$ & 0,258 & 1,031 \\
7 & $3.685,810$ & $-139,696$ & 0,245 & 1,204 \\
8 & $3.585,896$ & $-99,914$ & 0,175 & 1,176 \\
9 & $3.515,109$ & $-70,787$ & 0,124 & 1,153 \\
10 & $3.466,289$ & $-48,820$ & 0,086 & 1,270 \\
11 & $3.448,003$ & $-18,286$ & 0,032 & 1,080 \\
12 & $3.438,116^{\text {a }}$ & $-9,8870$ & 0,017 & 1,105 \\
13 & 3438,125 & 0,0090 & 0,000 & 1,272 \\
14 & $3.458,366$ & 20,241 & $-0,036$ & 1,012 \\
15 & $3.479,465$ & 21,099 & $-0,037$ & 1,022 \\
\hline
\end{tabular}

${ }^{\mathrm{a}}$ Gerombol maksimum

Tabel 1 nilai BIC untuk masing-masing gerombol, nilai BIC dan rasio perubahan BIC digunakan untuk menentukan jumlah gerombol maksimum yang terbentuk. Nilai rasio perubahan BIC pada gerombol ke-12 yaitu sebesar 0,017 dengan nilai BIC terkecil yaitu 3.438,116. Nilai rasio perubahan BIC tersebut mendekati nilai $c_{1}=0,04$. Dapat disimpulkan bahwa jumlah gerombol maksimum yang dihasilkan pada tahap pertama sebanyak 12 gerombol. Jumlah gerombol optimal didapat dari solusi yang memiliki nilai rasio pengukuran terbesar. Rasio perubahan gerombol untuk dua nilai rasio ukuran jarak terbesar pada solusi gerombol 2 dan gerombol 3. Rasio ukuran jarak antara kedua nilai tersebut adalah sebesar 1,046. Perbandingan nilai tersebut lebih kecil dari nilai batas konstanta $c_{2}=1,15$ yaitu pada rasio ukuran jarak $\left\{k_{2}\right\}$. Oleh karena itu, gerombol optimal yang terbentuk pada penelitian ini sebanyak 3 gerombol. Pendistribusian mahasiswa FMIPA Untan yang terbentuk disetiap gerombol dapat dilihat pada Tabel 2 berikut:

Tabel 2 Distribusi Hasil Gerombol

\begin{tabular}{rrrr}
\hline & \multicolumn{2}{c}{ N } & $\%$ \\
\hline Gerombol & 1 & 294 & 53,60 \\
& 2 & 186 & 33,90 \\
& 3 & 69 & 12,60 \\
& Total & 549 & 100 \\
\hline
\end{tabular}

Tabel 2 seluruh anggota sampel amatan terdistribusi ke dalam tiga gerombol yang terbentuk. Penyebaran setiap gerombol terlihat bahwa mahasiswa paling banyak terdapat pada gerombol satu, sedangkan pada gerombol dua yaitu 33,90\% pada tingkat kedua dan yang paling sedikit pada gerombol tiga.

\section{KARAKTERISTIK GEROMBOL}

Karakteristik setiap gerombol yang terbentuk dapat dilihat pada Tabel 3 dan Tabel 4 sebagai berikut: 
Tabel 3 Frekuensi dan Persentasi Peubah Kategorik

\begin{tabular}{rrrrrrrr}
\hline Peubah & \multicolumn{2}{c}{ Gerombol 1 } & \multicolumn{2}{c}{ Gerombol 2 } & \multicolumn{2}{c}{ Gerombol 3 } \\
& & $\mathrm{N}$ & \multicolumn{1}{c}{$\%$} & $\mathrm{~N}$ & \multicolumn{1}{c}{$\%$} & $\mathrm{~N}$ & $\%$ \\
\hline$X_{1}$ & 1 & 111 & 52,40 & 63 & 29,70 & 38 & 17,90 \\
& 2 & 183 & 54,30 & 123 & 36,50 & 31 & 9,20 \\
\hline$X_{2}$ & 1 & 93 & 50,80 & 66 & 36,10 & 24 & 13,10 \\
& 2 & 196 & 55,20 & 117 & 33 & 42 & 11,80 \\
& 3 & 5 & 45,50 & 3 & 27,30 & 3 & 27,30 \\
\hline$X_{3}$ & 1 & 294 & 62,20 & 179 & 37,80 & 0 & 0 \\
& 2 & 0 & 0,00 & 7 & 9,20 & 69 & 90.8 \\
\hline$X_{4}$ & 1 & 1 & 0,80 & 113 & 87,60 & 15 & 11,60 \\
& 2 & 180 & 74,00 & 4 & 1,90 & 32 & 14,80 \\
& 3 & 94 & 83,30 & 15 & 11,80 & 18 & 14,20 \\
& 4 & 3 & 25,00 & 8 & 66,70 & 1 & 8,30 \\
& 5 & 16 & 24,60 & 46 & 70,80 & 3 & 4,60 \\
\hline$X_{5}$ & 1 & 0 & 0,00 & 129 & 92,80 & 10 & 7,20 \\
& 2 & 294 & 71,70 & 57 & 13,90 & 59 & 14,40 \\
\hline
\end{tabular}

Tabel 4 Nilai Rataan Peubah Kontinu

\begin{tabular}{rrrrrrrrr}
\hline Peubah & \multicolumn{2}{c}{ Gerombol 1 } & \multicolumn{2}{c}{ Gerombol 2 } & \multicolumn{2}{c}{ Gerombol 3 } & \multicolumn{2}{c}{ Total } \\
& Rataan & Std deviasi & Rataan & Std deviasi & Rataan & Std deviasi & Rataan & Std deviasi \\
\hline$X_{6}$ & 80,8 & 5,29 & 81,8 & 4,76 & 78,28 & 6,63 & 80,82 & 5,41 \\
$X_{7}$ & 83,56 & 3,47 & 83,51 & 3,11 & 81,42 & 5,89 & 83,27 & 3,81 \\
$X_{8}$ & 55,32 & 10,43 & 58,53 & 10,03 & 51,43 & 12,62 & 55,92 & 10,81 \\
\hline
\end{tabular}

\section{Karakteristik Gerombol Satu}

Pada gerombol satu dicirikan memiliki karakteristik dengan jumlah mahasiswa lebih banyak dibandingkan gerombol lainnya. Pada jenis kelamin jumlah mahasiswa yang berstatus perempuan lebih banyak. Sebagian besar mahasiswa berasal dari kabupaten/kota luar daerah yang berada di Kalimantan Barat dan yang paling sedikit mahasiswa berasal dari luar Kalimantan Barat yaitu 5 mahasiswa. Status sekolah seluruh mahasiswa berasal dari sekolah negeri. Pada gerombol satu banyak orang tua yang hanya lulusan SMP. Oleh karena itu, banyak orang tua mahasiswa yang bekerja sebagai petani, pedagang, dan swasta. Tingkat kepentingan dari peubah kategorik dan kontinu untuk masing-masing gerombol, dapat dilihat pada Gambar 1 Peubah kategorik menggunakan uji ChiSquare dan peubah kontinu menggunakan uji $t$-Student sebagai statistik uji.
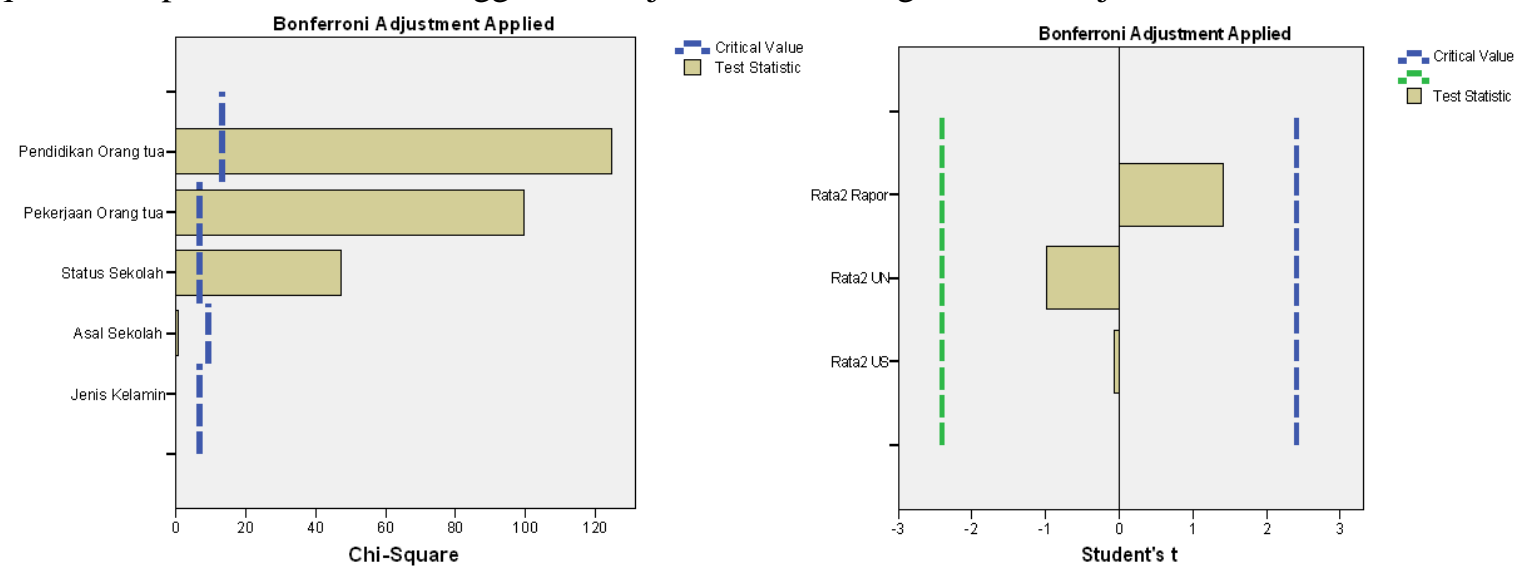

Gambar 1 Tingkat Kepentingan Gerombol Satu 
Peubah yang berpengaruh terhadap pembentukan setiap gerombol dapat dilihat pada Gambar 1 . Apabila terdapat peubah yang memiliki statistik uji lebih besar dari nilai kritis (garis lurus vertikal) maka peubah berpengaruh terhadap pembentukan gerombol. Gerombol satu pembentukan gerombol dipengaruhi oleh peubah pendidikan orang tua, pekerjaan orang tua, dan status sekolah, sedangkan peubah yang tidak berpengaruh pada peubah kategorik untuk gerombol satu yaitu asal sekolah dan jenis kelamin. Pembentukan gerombol satu tidak berdasarkan peubah-peubah kontinu yang digunakan.

2. Karakteristik Gerombol Dua

Anggota gerombol dua dicirikan dengan karakteristik mahasiswa lebih banyak dibandingakan gerombol tiga. Berdasarkan Tabel 3 sebagian besar mahasiswa berjenis kelamin perempuan. Berdasarkan status sekolah, banyak mahasiswa yang berasal dari sekolah negeri dan asal sekolah mahasiswa dari kabupaten di Kalimantan Barat. Gerombol dua terdapat beberapa mahasiswa berstatus sekolah swasta, terdapat tujuh mahasiwa yang berasal dari sekolah swasta, berbeda dengan gerombol satu yang tidak terdapat mahasiswa yang berasal dari sekolah swasta. Pendidikan orang tua pada gerombol dua memiliki jenjang pendidikan tamatan SD, S1 dan S2 dan sebagian besar orang tua mahasiswa banyak yang bekerja sebagai PNS atau BUMN. Orang tua mahasiswa yang bekerja sebagai petani, pedagang dan swasta lebih sedikit dengan jumlah 57 orang tua mahasiswa. Peubah yang berpengaruh dalam gerombol dua adalah adalah pendidikan orang tua, pekerjaan orang tua, status sekolah, rata-rata nilai ujian sekolah dan rata-rata nilai ujian nasional.
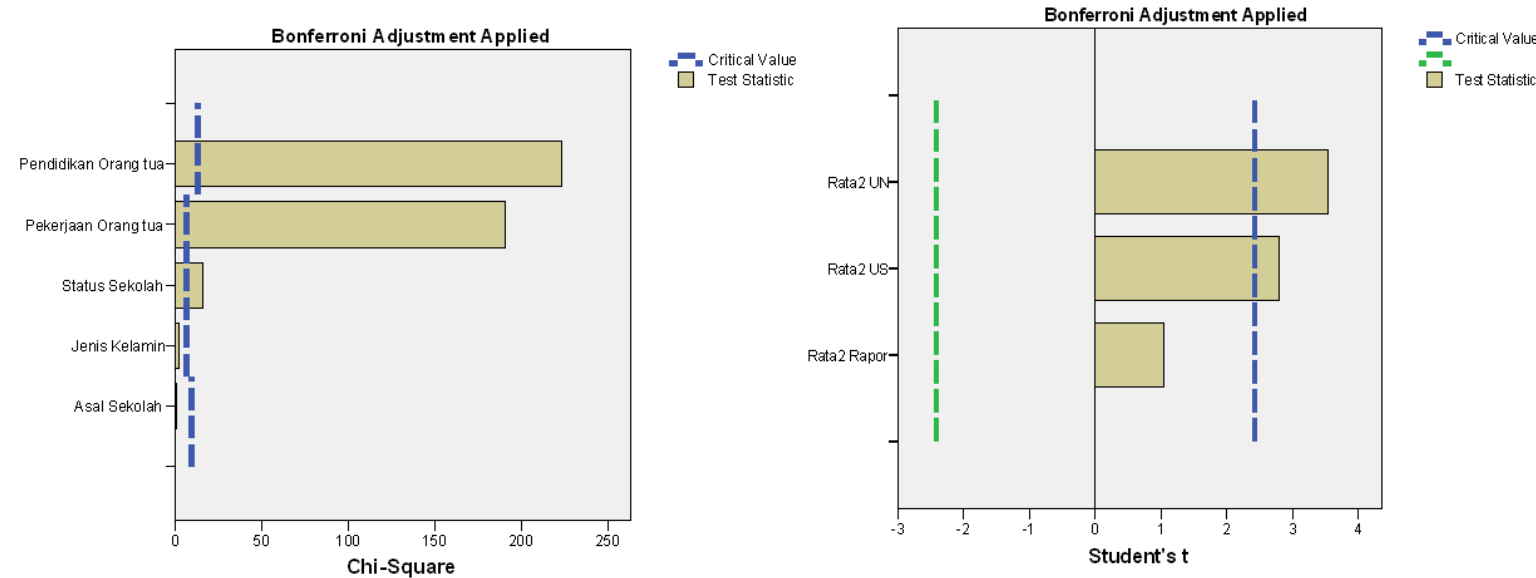

Gambar 2 Tingkat Kepentingan Gerombol Dua

\section{Karakteristik Gerombol Tiga}

Anggota pada gerombol tiga dicirikan dengan gerombol yang memiliki mahasiswa lebih sedikit dibandingan gerombol satu dan gerombol dua. Berbeda dengan gerombol satu dan gerombol dua, pada gerombol tiga mahasiswa laki-laki lebih banyak. Peubah yang berpengaruh pada gerombol tiga dapat dilihat pada Gambar 3 berikut:
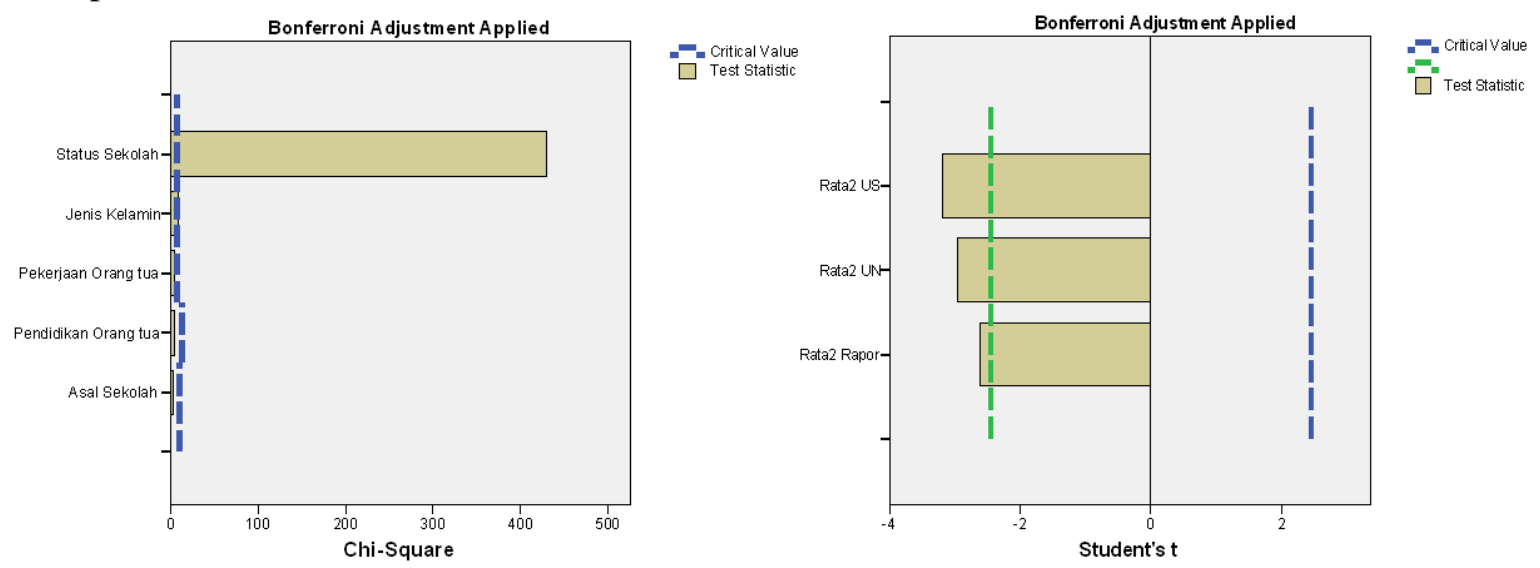

Gambar 3 Tingkat Kepentingan Gerombol Tiga 
Pada Gambar 3 peubah yang berpengaruh dalam gerombol tiga adalah status sekolah, jenis kelamin, pekerjaan orang tua, rata-rata nilai ujian sekolah, rata-rata ujian nasional dan rata-rata nilai rapor. Semua peubah kontinu pada gerombol tiga mempengaruhi gerombol. Berbeda dengan gerombol satu dengan seluruh mahasiswa berstatus sekolah negeri, karakteristik dari gerombol tiga adalah mahasiswa yang seluruh anggota gerombol berstatus sekolah swasta. Pada asal sekolah mahasiswa, banyak mahasiswa yang berasal dari kabupaten/kota di Kalimantan Barat dari pada mahasiswa yang berasal dari Pontianak ataupun dari luar daerah Kalimantan Barat, gerombol tiga dan gerombol dua memiliki ciri karakteristik yang sama pada jumlah mahasiswa yang berasal dari luar Kalimantan Barat yaitu sebanyak 3 mahasiswa.

\section{KESIMPULAN}

Hasil penggerombolan mahasiswa dengan menggunakan metode Two Step Cluster menghasilkan 3 gerombol optimal. Gerombol satu dicirikan memiliki karakteristik dengan jumlah mahasiswa berjenis kelamin perempuan lebih banyak. Gerombol satu seluruh mahasiswa berasal dari sekolah negeri, tetapi pada peubah kontinu tidak ada peubah yang mempengaruhi gerombol. Gerombol dua dicirikan dengan karakteristik mahasiswa lebih banyak berasal dari kabupaten di Kalimantan Barat dari pada kota Pontianak atau dari luar Kalimantan barat. Pada pendidikan orang tua mahasiswa lebih banyak lulusan SD, S1 dan S2 daripada jenjang pendidikan lainnya. Peubah kontinu yang mempengaruhi gerombol dua yaitu rata-rata nilai ujian sekolah dan rata-rata nilai ujian nasional. Gerombol tiga merupakan gerombol yang paling sedikit jumlah mahasiswanya. Gerombol tiga dicirikan dengan karakteristik mahasiswa seluruhnya berstatus dari sekolah swasta. Sebagian besar mahasiswa berasal dari kabupaten di Kalimantan Barat, dan pendidikan orang tua berasal dari tingkat SMP. Pada gerombol tiga semua peubah kontinu mempengaruhi gerombol.

\section{DAFTAR PUSTAKA}

[1]. Mattjik AA, Sumertajaya IM. Sidik Peubah Ganda Dengan Menggunakan SAS. edisi pertama: IPB Press; 2011.

[2]. Alwi W, Hasrul M. Analisis Klaster Untuk Pengelompokan Kabupaten/Kota di Provinsi Sulawesi Selatan Berdasarkan Indikator Kesejahteraan Rakyat. Jurnal MSA (Matematika dan Statistika serta Aplikasinya). 2018; 6(1):35-40.

[3]. Putri WDY, Sumertajaya IM, Erfiani. Analisis Gerombol Menggunakan Metode Two Step Cluster. Forum Statistika dan Komputasi. 2007; 12(1):18-23.

[4]. Rahmawati MA, Dewi YS, Hadi AF. Pengelompokan Desa di Kabupaten Jember Berdasarkan Peubah Potensi Desa Menggunakan Metode Two Step Clustering Dengan Jarak Log-Likelihood. Universitas Jember Jurnal (UNEJ). 2014; 90(1):1-5.

[5]. Mongi CE. Penggunaan Analisis Two Step Clustering Untuk Data Campuran. Jurnal de Cartesian (JdC). 2015; 4(1):9-19.

[6]. Bacher J, Wenzig K, Vogler M. SPSS Two Step Cluster. Universitas Erlangen-Nurnberg. 2004.

[7]. Bustami, Abdullah D, Fadlisyah. Statistika Terapannya Pada Bidang Informatika. Edisi pertama: Graha Ilmu; 2014.

INTAN APRILIA HAPSARI

DADAN KUSNANDAR

NURFITRI IMRO’AH
: Jurusan Matematika FMIPA Untan Pontianak, intanhapsari@student.untan.ac.id

: Jurusan Matematika FMIPA Untan Pontianak, dkusnand@untan.ac.id

: Jurusan Matematika FMIPA Untan Pontianak, nurfitriimroah@math.untan.ac.id 